Estudios de

lingüística inglesa aplicada

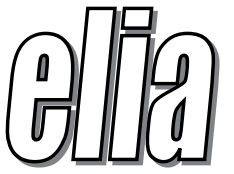

\title{
TOOL USAGE AND EFFECTIVENESS AMONG L2 SPANISH COMPUTER WRITERS
}

\section{USO Y EFECTIVIDAD DE HERRAMIENTAS EN LA ESCRITURA POR ORDENADOR EN ESPAÑOL COMO SEGUNDA LENGUA}

\author{
Daniel G. Tight \\ University of Saint Thomas, Minnesota, USA \\ dan.tight@stthomas.edu
}

DOI: http://dx.doi.org/10.12795/elia.2017.i17.07

This study describes the tools employed by intermediate learners of Spanish $(N=12)$ writing short, low-stakes compositions via computer. Echo360 screencasting software was used to create video recordings of five compositions per participant over a three-month period, as well as to capture a think-aloud protocol on the final task. Results reveal that sixth-semester learners make frequent use of online bilingual dictionaries and translators, regularly depend on the word processor's spelling and grammar checkers, and use a variety of techniques to make diacritics and special characters in their writing. Despite high levels of overall success with both internet and word processing resources, errors were common in the texts generated, with grammatical errors occurring more than vocabulary and spelling mistakes combined, at a rate of just over 6 per 100 words. Taken together with previous research, these findings paint a more complete picture of L2 computer writing in Spanish as a demanding 
task requiring pedagogical intervention to maximize the effectiveness of available resources, even for college majors and minors.

Key words: computer writing, L2 writing tools, online dictionaries, spell checker, grammar checker, diacritic generation

Este estudio describe las herramientas empleadas por aprendices intermedios de español $(N=12)$ mientras escribian breves composiciones informales en ordenador. El programa de captura de pantalla Echo360 se usó para crear videograbaciones de cinco composiciones por participante a lo largo de un periodo de tres meses, así como para registrar un protocolo de pensar en voz alta durante la última tarea. Los resultados revelan que los aprendices de sexto semestre hacen uso frecuente de los diccionarios bilingües y traductores en linea, a menudo recurren a los correctores ortográficos y gramaticales del procesador de textos, y emplean una variedad de técnicas para producir signos diacríticos y caracteres especiales en su escritura. A pesar de altos niveles de éxito generales con estos recursos de internet y del procesador de textos, habia gran cantidad de errores en los textos generados, con más errores gramaticales que errores léxicos y ortográficos juntos, a una frecuencia de más de 6 por cada 100 palabras. Estos hallazgos, apoyados en investigaciones previas, presentan un panorama más completo de la escritura en español L2 por ordenador como una tarea exigente que requiere intervención pedagógica para maximizar la efectividad de los recursos disponibles, incluso para los universitarios especializados en materias lingüísticas.

Palabras clave: escritura por ordenador, herramientas de escritura en la L2, diccionarios en línea, corrector ortográfico, corrector gramatical, generación de signos diacríticos

\section{Introduction}

More than a decade ago Pennington (2004) stated that "the word processor is the writing tool of choice for all people in the modern world, and writing teachers no longer have any realistic option besides writing in a computer context" (p. 79), signaling an end to the debate over writing by hand

ELIA 17, 2017, pp. 157-182～DOI:http://dx.doi.org/10.12795/elia.2017.i17.07 
versus computer that had characterized much of the second language (L2) writing literature. Though computer-based writing has evolved to include technologies such as email, blogs, wikis, and social media, in addition to the word processor, many second language teachers continue to assign, and many learners to generate, a substantial amount of writing in "traditional" forms such as essays, reflections, short stories, and research papers. While the final product that the course instructor sees may fairly closely resemble the kind of writing produced by previous generations, the means for arriving at that final product may not. The current article provides insight into how today's university L2 students carry out a variety of such writing tasks using contemporary technology resources. In doing so, it both informs L2 composition teachers and empowers them to intervene as needed.

\section{Background Literature}

The task of writing in a second language is a "laborious" one (Roca de Larios, Marín, \& Murphy, 2001: 521), punctuated with starts and stops, resulting in a "constant interplay of thinking, writing, and rewriting" (Zamel, 1983: 172). Elola and Mikulski (2016), for example, found that their intermediate students of Spanish as foreign language $(n=6)$ paused for an average of $44.3 \%$ of their composition time, a figure in line with what has been observed for other second language writers (cf. Bosher, 1998). Chenoweth and Hayes (2001), who investigated $2^{\text {nd }}$ - and $3^{\text {rd }}$-year university learners of L2 German $(n=7)$ and French $(n=6)$, report that this sort of writing behavior led to an average output of only 10.8 words per minute, in bursts of just two to three words at a time. Elola and Mikulski found that their learners, who were of a slightly higher level and wrote via computer rather than manually, achieved a somewhat higher 13.8 words per minute.

The challenge that writers face when expressing themselves in their L2 manifests itself, of course, not only in hesitancy, but also in various kinds of non-target-like use. In L2 Spanish, for example, Chastain (1990) found that his $3^{\text {rd }}$ - and $4^{\text {th }}$-year university Spanish learners $(N=14)$ erred in using approximately $4.7 \%$ of words, with lexical errors (57.2\%) predominating over grammatical ones (38.7\%). Elola and Mikulski (2016), on the other 
hand, observed a preponderance of grammatical errors $(51.0 \%)$ for L2 learners of Spanish, though lexical errors were also common $(37.3 \%)$. Orthographic errors $(9.8 \%)$ were relatively rare. Overall, these errors influenced $4.7 \%$ of words produced by their L2 learners. Writing research for other L2s has revealed a similar prevalence of lexical and morphosyntactic errors over orthographic ones, though with varying relative frequencies (cf. Bardovi-Harlig \& Bofman, 1989 and Ferris, 2002 for ESL; Kuiken \& Vedder, 2007 for French and Italian).

Luckily, when faced with this protracted and error-prone task of expressing themselves in a second language, today's learners have a variety of tools at their disposal. One of the most well known is, of course, the dictionary. Elola, Rodríguez-García, and Winfrey (2008) report a variety of uses for dictionaries during L2 writing, including:

1. To correct grammar errors

2. To understand verb conjugations

3. To check spelling

4. To look up unknown words

5. To verify the meaning of L2 words

6. To enhance writing style

In reality, however, Frankenberg-Garcia (2011) notes that language learners principally consult bilingual dictionaries to discover how to express an L1 concept in the L2 or to confirm the meaning of L2 words. Loucky (2010) concurs that L2 learners overwhelmingly prefer bilingual to monolingual dictionaries, likely because use of the L1 serves as a "problem-solving device" (Manchón, Roca de Larios, \& Murphy, 2000: 32), allowing them to continue writing even when faced with a gap in their lexical knowledge (Krapels, 1990).

More and more, L2 learners, instead of carrying around paper dictionaries, have turned to online resources to meet their composing needs. In a survey of 250 post-secondary L2 learners, Jin and Deifell 
(2013) discovered that a full $85 \%$ of respondents reported using online dictionaries, and doing so primarily for writing tasks. One can only assume that an even higher percentage of learners makes use of these resources now several years later.

For Spanish language learners, Jin and Deifell (2013) note that the most popular aids employed were, in order: WordReference.com, Google Translate, and $\mathrm{Span}_{j} \mathrm{ShD}_{i} \mathrm{ct}$. They also note that learners have a very positive impression of online Spanish dictionaries as "free, fast, convenient, easy to use, and up-to-date" (p. 523). Such benefits of online dictionaries and translators have also been demonstrated empirically. Elola et al. (2008), for example, report that their university L2 Spanish learners of varying levels of proficiency $(N=12)$ were more effective at a variety of tasks including composing, revising, and translating when using online tools than without their assistance.

Despite the advantages of dictionaries and translators, care must be taken in using them. Christianson (1997) cautions that "no matter which dictionary is used, its value depends on the user more than the dictionary itself" (p. 34), noting that $42 \%$ of the words that his Japanese EFL students $(N=51)$ looked up were then used incorrectly. Elola et al. (2008) found certain classes of words and phrases to be especially problematic, including abstract words, collocations, set phrases, transitions, and words that represent more than one part of speech. O'Neill's (2012) $3^{\text {rd }}$ - and $4^{\text {th }}$ semester university learners of L2 French $(N=32)$ also recognized various shortcomings of their online translator, including greater inaccuracy in rendering phrases (as opposed to isolated words) in the target language.

Of course, online dictionaries and translators are not the only tools to which L2 writers have access nowadays. Among the various other tools available, two that are nearly ubiquitous, though little researched, are the spell checker and grammar checker. Spell checkers function by scanning a given text and identifying any words that do not appear in the application's dictionary (Rimrott \& Heift, 2008). Grammar checkers, on the other hand, seek to detect errors in the usage of words that do appear in the dictionary. 
In one of the few studies to investigate the effectiveness of spell checkers, Rimrott and Heift (2008) examined the efficacy of Microsoft Word's spell checker for a group of first- and second-semester university L2 German learners $(N=48)$. The authors found that the spell checker was able to successfully correct $62 \%$ of their 1027 unique spelling errors. However, it also failed to flag $6 \%$ of the errors. The remaining errors were detected, but the spell checker was unable to propose an appropriate correction. Rimrott and Heift conclude that Microsoft Word's spell checker, designed primarily to help native speakers with performance errors, is not an ideal tool for second language learners, who tend to make more serious competence errors.

Rimrott and Heift's (2008) call for spell checkers tailored to the needs of second language learners resonates with a similar request from Heift and Schulze (2007) regarding grammar checkers. Pennington and Brock (1992), for example, found that an early iteration of a grammar checker led to surface-level revision at the expense of meaning-related revision among their university ESL writers $(n=2)$. Furthermore, the authors report that participants' use of the software did not help them learn to become better proofreaders and editors themselves, but rather led to increased reliance on the text analyzer. In the case of advanced L2 French learners, Burston (2001) found a combination spelling and grammar checker to be quite effective at identifying orthographic and morpho-syntactic errors, leading to notably more target-like usage than in a control group. Here too, though, students struggled to improve in their own editing and proofreading skills without further intervention from the teacher. Finally, Buck (2008) has noted a distracting effect for both first- and second-language writers of the colored underlining generated by MS Word when it detects a spelling or grammar error.

\section{Method}

\subsection{Research Questions}

Given the constant evolution of technology, persistent research into L2 computer writing is needed. As experts in the field have long proposed 
(e.g., Pennington, 1999), this need is especially great for L2s other than English. Mikulski and Elola (2011) specifically call for more research into the writing of L2 Spanish learners, a population whose number at the post-secondary level in the U.S. alone totaled almost 800,000 in 2013 (Goldberg, Looney, \& Lusin, 2015). Within this population, Elola and Mikulski (2016) point to the need for investigations that include a larger sample of compositions from different genres, as well as a protocol to understand the thoughts that underlie the composition process. Overall, there is a void in the existing research around the use of internet resources, spell checkers, and grammar checkers by L2 Spanish computer writers, as well as a lack of information about how this group generates special characters and diacritics. The current study addresses each of these gaps by answering the following research questions:

1. What tools and resources do intermediate L2 Spanish learners use while completing low-stakes writing assignments via computer?

2. How successful are they with those tools and resources?

\subsection{Participants}

Undergraduates from a sixth-semester Spanish composition course $(N=$ 12) at a private university in the Midwestern United States volunteered to participate in the investigation during normal class meeting times. All were of "traditional" college age and were native speakers of English studying Spanish as a second language. The majority planned to major or minor in Spanish, and the course in question was required of all such students.

\subsection{Data Collection}

After verifying participant consent, data were collected by the author, who was also the instructor of the course, beginning in the second week of the semester and ending in the fourteenth week. During this time, participants wrote a series of five short, low-stakes compositions during portions of five class days. These pieces of writing were considered "low-stakes" because they were not handed in or graded in any way. At the same time, 
learners did have some incentive to do their best, since the instructor often asked for volunteers to share their completed work with the class for group comment/correction. The topics for the compositions, available in the appendix, represented a variety of genres, including description, narration, and argumentation.

Data were collected in a university language lab equipped with PC computers, internet access, headsets with integrated microphone, and a variety of software. Prior to beginning each composition, the author introduced the topic and instructed participants to launch Echo360 screen recording software, which then ran in the background. Participants were allowed to write until most were finishing or done, at which time those still working were instructed to finish up in the next minute or two. Participants saved their video recordings as a .wmv file to a server accessible by the researcher.

The fifth composition included a task not present in the previous four-a think-aloud protocol. This involved learners speaking aloud all thoughts they had as they carried out the writing assignment. This sort of introspective activity has commonly been used as a window into "the covert process of writers at work" (Roca de Larios, Murphy, \& Marín, 2002: 13) and was intended to complement the information available through the video recordings. Prior to beginning the fifth composition, the investigator explained how a think-aloud protocol worked, and showed participants a short video example of someone completing such a protocol (in English, while doing a task unrelated to writing). In order to avoid biasing what learners might say, they were given no instruction other than to speak aloud all of their thoughts, and were occasionally reminded to continue doing so. The audio, as spoken into the headset microphone, was captured along with the video by Echo360.

\subsection{Data Analysis}

Prior to a more fine-grained examination of the data, general quantitative analysis was performed. Specifically, three features - writing time, length, and fluency - of the first four compositions were considered. Given the 
unique nature of think-aloud tasks (Roca de Larios et al., 2002), the fifth composition was limited to more qualitative analysis. Writing time was operationalized, similar to Chenoweth and Hayes (2001), as the duration between the first composition-related action (e.g., typing, launching a web browser to look up a word) and the last. Length was defined as the total number of words in the final version of each composition. As in Chenoweth and Hayes (2001), fluency was formalized as the number of words written per minute.

Since L2 writing has been characterized as "alternating sequences of pausing and writing" (Schilperoord, 1996: 21), it was also considered prudent to get a sense for how these behaviors manifested themselves. To that end, pause time and average burst length were calculated for the first composition. Pause time was determined by summing up all periods of inactivity or internet consultation lasting at least two full seconds (following Elola and Mikulski, 2016). Burst length was operationalized as the number of words written between pauses or between a pause and some other non-text-generating activity (e.g., changing the keyboard language, using the spell checker).

In order to answer research question 1, recordings of the first four compositions were analyzed for the use of writing tools, which were grouped into the following types-i) internet resources, ii) Microsoft Word's spell checker and grammar checker, and iii) the primary means of making accented and special characters. For those participants who made use of internet resources (e.g., online dictionaries, translators), we tracked which websites they consulted, how often, and the subject of each consultation. For those who made use of the spell checker and the grammar checker, we again noted the number of consultations and the structures in question. ${ }^{1}$ In the case of accent marks and other special characters, we recorded which, if any, keyboard (English, Spanish, or US-International) or other technique learners predominantly used to generate them.

In answering research question 2, we looked at all uses of an internet resource, the spell checker, and the grammar checker. ${ }^{2}$ Each consultation was then judged as successful or unsuccessful based on whether it resulted in target-like language or not. In the latter case, errors were classified 
as relating to vocabulary, grammar, or spelling. Vocabulary errors were considered those in which learners used an inappropriate lexical item given the context (e.g., provenir instead of proveer to express 'provide'). Grammar errors included those related to gender/number agreement (e.g., Las ventanas están roto), verb form (e.g., Ellos no tengan mucha experiencia), the omission of necessary words (e.g., Cuando el niño está preparando tirar las piedras), and the inclusion of extraneous words (e.g., Pide para su dinero), among others. Spelling errors were those where a word was semantically appropriate for a given context, but orthographically flawed (e.g., despues, butón).

In order to get a sense not only of when technology resources were useful to participants but also of when such tools failed to assist them, all other errors in the compositions were also identified, categorized, and tallied. Repeated instances of the same error were counted only once per composition. Since texts were not of uniform length, total errors of each type were divided by the number of words in a composition in order to arrive at an "accuracy ratio" of the kind described by Kroll (1990: 146).

\section{Results}

\subsection{General Quantitative Analysis}

As can be seen in Table 1, participants spent, on average, almost 11 minutes producing their texts. However, this writing time varied across compositions, as well as among individuals. For composition 1, for example, the shortest writing time was just 7:44, while the longest lasted 10:50. For composition 4, by comparison, writing times ranged from 9:49 to $14: 09$.

ELIA 17, 2017, pp. 157-182～DOI:http://dx.doi.org/10.12795/elia.2017.i17.07 
Table 1

Mean writing time, length, and fluency

\begin{tabular}{llll}
\hline Task & Writing time (min:sec) & Length (words) & Fluency (words/min) \\
\hline Composition 1 & $9: 26(0: 49)$ & $100.0(24.9)$ & $10.6(2.5)$ \\
Composition 2 & $11: 07(1: 44)$ & $130.4(36.3)$ & $11.7(2.5)$ \\
Composition 3 & $11: 03(0: 54)$ & $125.8(42.7)$ & $11.4(4.0)$ \\
Composition 4 & $11: 43(1: 10)$ & $123.6(32.9)$ & $10.6(3.1)$ \\
Overall & $10: 50(1: 27)$ & $119.9(35.7)$ & $11.1(3.0)$ \\
\hline
\end{tabular}

Note: Standard deviations are given in parentheses.

The variation observed for writing time also characterized the length of the texts produced. Though the average number of words written across all compositions was nearly 120 , the difference between the averages on compositions 1 and 2 was more than 30 words. Individual variation was again notable in this measurement. One learner, for example, wrote only 59 words in the initial composition, reaching a maximum of 88 words on the third assignment, while a classmate never wrote fewer than 110 words, exceeding 200 words twice.

In terms of fluency, participants wrote, on average, just over 11 words per minute, a rate slightly lower on the first and last tasks and marginally higher on the intervening tasks. Individual variation for this metric was also clear, as two participants wrote as little as 7.2 words per minute, while three others wrote in excess of 15 words per minute on at least one composition, reaching a maximum 20.4.

On average, $57.1 \%(5: 24)$ of participants' total writing time on the first composition was spent pausing. The participant who paused least still did so $45.8 \%$ of the time, while the one who paused most reached $63.2 \%$. In between pauses, learners generated text in bursts that averaged between 1.8 and 4.4 words, with an overall mean burst length of 3.5 words.

\subsection{Research Question 1}

One important component of participants' pausing behavior was to make ELIA 17, 2017, pp. 157-182～DOI:http://dx.doi.org/10.12795/elia.2017.i17.07 
use of internet resources, something all learners did at one time or another. On average, learners consulted web resources 6.3 times per composition. One participant did so 17 times during a single task, while there were also three compositions produced with no internet use. As can be seen in Table 2 , only a small number of websites were ever consulted during the course of the study, led by Google Translate.

In the vast majority of cases, learners looked up how to express an isolated English word in Spanish. These words covered a variety of classes, including nouns (e.g., glass, sheet, window), verbs (e.g., throw, fix, click), adjectives (e.g., smooth, pristine, bumpy), adverbs (e.g., approximately, conveniently, suspiciously), and prepositions (e.g., by, after, behind). On other occasions, participants queried short phrases (e.g., dream job, in order to, lose hope) or even whole clauses in English (e.g., the people would benefit, they are smart, it is the size of a coconut). With less frequency, they also looked up a Spanish word (e.g., estorbar, obviamente, minimizar) to make sure that it was appropriate for a given context.

Table 2

Internet resources consulted

\begin{tabular}{lcc}
\hline Website & \# of consultations & Success rate \\
\hline Google Translate & 114 & $88.6 \%$ \\
WordReference.com & 111 & $97.3 \%$ \\
Span $i$ shDict & 70 & $92.9 \%$ \\
Merriam-Webster Spanish Central & 5 & $60.0 \%$ \\
Total & 300 & $92.3 \%$ \\
\hline
\end{tabular}

Participants, all of whom used Microsoft Word to create their compositions, also made use of the word processor's spell checker and grammar checker. On average, the spell checker was used to address 2.2 unique errors per composition (e.g., arpirar $\rightarrow$ aspirar, estuadir $\rightarrow$ estudiar, conoci $\rightarrow$ conoci), though individual reliance varied from 0 to 7 uses. It is important to note that the version of Microsoft Word used in the language lab also had the auto-correct feature activated. As such, some common spelling errors that participants made were fixed automatically 
as they typed (e.g., tambien $\rightarrow$ también, nino $\rightarrow$ niño, estan $\rightarrow$ están), without learners needing to notice them or intervene in any way. ${ }^{3}$ Learners also used the grammar checker between 0 and 7 times per composition, averaging 1.4 unique uses per text to address a variety of issues (e.g., un buen idea $\rightarrow$ una buena idea, ellos hace $\rightarrow$ ellos hacen, su materiales $\rightarrow$ sus materiales).

The final tools analyzed were the various methods for making accented characters. During the majority of composing sessions, 35 of 48 , participants made at least one accent mark or other special character. The primary means of doing so were by using the Spanish keyboard (14 sessions), English keyboard (10), US-International keyboard (7), and copying and pasting the character from elsewhere (4). In the remainder of cases (13), participants made no attempt to generate accents on their own, instead relying on auto-correct, the spell checker, or the grammar checker.

\subsection{Research Question 2}

Also evident from Table 2 is the fact that the small number of websites consulted led to a high level of overall success. Of note, however, is that Google Translate, which led in popularity, trailed both WordReference. com and $\operatorname{Span}_{j} \mathrm{ShD}_{i} \mathrm{ct}$ in accuracy. When errors did occur, they included missteps such as selecting lesiones for "batteries" (for an electronic device), fijar for "to fix" (something that is broken), and un poco realista for "unrealistic."

Success with the spell checker and grammar checker was even greater than with internet resources. Use of the spell checker yielded target-like responses $95.2 \%$ of the time, with only sporadic errors such as the selection of pristiño instead of prístino as a correction for pristino. ${ }^{4}$ Employment of the grammar checker facilitated $95.7 \%$ accuracy, only leading users astray by suggesting changes such as estarán, instead of estuvieran, when the incorrect form estaran had been used for the imperfect subjunctive.

This high level of success with dictionaries, translators, the spell checker, and the grammar checker does not mean, however, that 
compositions were devoid of errors. Rather, data analysis revealed errors present in all three categories of surface features - vocabulary, grammar, and spelling. As can be seen in Table 3, grammar errors predominated, with an overall average above 6 errors per 100 words. There was also substantial variation among individuals with respect to grammatical precision, from as few as 0.9 errors per 100 words on a given composition to as many as 18.6.

Table 3

Mean errors per 100 words

\begin{tabular}{llll}
\hline Task & Vocabulary & Grammar & Spelling \\
\hline Composition 1 & $3.2(2.0)$ & $5.5(4.6)$ & $1.6(1.9)$ \\
Composition 2 & $1.8(1.3)$ & $6.0(2.8)$ & $1.0(1.9)$ \\
Composition 3 & $2.4(1.7)$ & $6.8(3.4)$ & $0.3(0.5)$ \\
Composition 4 & $2.1(1.9)$ & $6.1(4.0)$ & $1.1(1.1)$ \\
Overall & $2.4(1.8)$ & $6.1(3.7)$ & $1.0(1.5)$ \\
\hline
\end{tabular}

Note: Standard deviations are given in parentheses.

While no participant managed to generate a single composition free of grammatical errors, such was not the case with vocabulary and spelling. Five different learners, in fact, produced a text with no vocabulary errors, and one of them did it three times. Success with spelling was even higher, where 23 of 48 compositions were error free. On the other end of the spectrum, the highest incidence of vocabulary errors was 7.4 per 100 words, and with spelling the maximum reached 6.7 errors per 100 words.

\section{Discussion}

The current study confirms that the composition process for sixth-semester university language majors and minors continues to be a challenging one. Overall, participants wrote at a modest rate (11.1 words/minute) comparable to Bosher's (1998) ESL writers (6.7-11.9 words/minute) and Chenoweth and Hayes' (2001) L2 French and L2 German learners (10.8 words/minute). This pace is somewhat lower, however, than what Elola 
and Mikulski (2016) observed for their intermediate L2 Spanish learners (13.8 words/minute), though some of this variance might be related to the fact that Elola and Mikulski's learners were from the U.S. Southwest, where the influence of Spanish is more pervasive, and were writing about previously discussed topics.

The present investigation is unique in reporting the average burst length of L2 Spanish writers. The typical size (3.5 words), though seemingly unimpressive, does surpass the burst length (2.4 words) witnessed by Chenoweth and Hayes (2001) for third- and fifth-semester L2 learners of French and German. Perhaps even more interesting is that it approaches the figure reported for their subjects when writing in their native English ( 3.7 words). Whether the participants in the present study would generate text in similar length bursts in their L1 must remain an open question.

Further testament to the demanding nature of composing in the L2 is provided by the amount of time dedicated to pausing - just over $57 \%$ of the time on the first composition. This extended amount of time is needed because, as one participant expressed on the think-aloud, "it gets ... a little overwhelming with all the ideas and then thinking of what to write, and ... remembering all of the different kinds of conjugations and different tenses" (Participant \#6). Pause time from the current study falls between those observed by Bosher (1998) for prospective college students writing in L2 English (42\%-73\%) and by Elola and Mikulski (2016) for L2 Spanish learners (38\%). The sizeable difference in pause time between Elola and Mikulski's L2 learners and those in the current study is noteworthy. While this discrepancy may have to do with factors such as task familiarity and sample size, it is also potentially related to language proficiency, a variable that was not assessed in either study, but which would seem important to track in future L2 writing research. ${ }^{5}$

To aid in the challenging composition process, learners in the current study frequently made use of online dictionaries and translators during this pause time. This practice was observed for all participants, more than the $87.5 \%$ Jin and Deifell (2013) report. As Loucky (2010) suggests, learners preferred bilingual tools, in fact never consulting any monolingual 
dictionary. The most popular resources consulted, in order, were Google Translate, WordReference.com, and $\mathrm{Span}_{i} \mathrm{shD}_{i} \mathrm{ct}$. These same three were found by Jin and Deifell to be the favorites of Spanish learners, though with WordReference.com well ahead of Google Translate. Jin and Deifell's survey respondents also indicated that they frequently consulted more than one online resource, though such was not the case in the current study. Rather, with few exceptions, a given participant would choose one online resource and use it exclusively for the entire composition, and often for all compositions.

The primary uses of these online resources were, as FrankenbergGarcia (2011) proposes, to look up how to express an English word or phrase in the L2 and to confirm what a word in the L2 meant in English. Such uses help to illustrate the important role of the L1 in L 2 composing. When faced with a lexical obstacle, the learner is able to lean on knowledge of the native language as a way to "sustain the composing process" (Krapels, 1990, pp. 49-50), as was evident from the following comments, taken from the think-aloud protocol of the final composition:

- “'Novel.' How do you say, 'novel'? [Looks up 'novel' in Google Translate.] Novela." (Participant \#3)

- 'Let's see, 'history,' I know 'history'... la historia. Is that 'story,' or 'history'? [Looks up 'history' in Google Translate.] Oh, la historia." (Participant \#4)

- “Además...si yo tuviera las resources, ¿cómo decir resources? [Looks up 'resources' in WordReference.com.] Um...'recurso'? [Clicks on recurso in WordReference.com to see English translation.] Okay. Relos recursos." (Participant \#7)

Other uses of online resources that Elola et al. (2008) list, such as consulting a verb conjugation, were infrequent in the current study.

Overall, the online resources consulted were effective, though not all were equally beneficial. In fact, the most commonly consulted-Google Translate - was only the third most advantageous. One reason for this is that, just as Jin and Deifell (2013) report, participants in the current study frequently used Google Translate to look up multiple-word phrases (e.g., 
"down the street," "for a profit"), or even entire sentences (e.g., "There are more students than jobs."). Thus, there were more chances in many Google Translate consultations to produce a non-target-like element. On the other hand, WordReference.com, the most effective online resource overall, was used primarily to consult individual words. This site, in addition to giving a variety of translations for isolated words and their collocations, includes example sentences in English and Spanish, which could have contributed to its advantage.

When learners did make errors after consulting online resources, they were often of the kinds Elola et al. (2008) describe, including:

- abstract or domain-specific terms: e.g., the use of the verb chasquear to express 'to click a button'

- items of multiple grammatical categories: e.g., the use of ronda to say that an object is 'round'

- discourse markers: e.g., the use of en vez de (with nothing after it) to express 'instead'

Also common was the incorrect selection of a cognate, such as panel for '(window) pane.' Other times, the learner simply had problems selecting the correct L2 equivalent of an L1 word that had several, as when one participant chose to use cualquier to express 'there wouldn't be any deaths.' In addition to online resources, participants also used other tools in the current study. All but one of the learners made use of the spell checker, and most did so on each of the compositions. Representative comments on the think-aloud included:

- [Uses the spell checker to change musisco to músico] "And usually if I spell something wrong I just...fix it, when it underlines it." (Participant \#6)

- [Modifies capáz to capaz with spell checker] "And that doesn't have an accent. Okay." (Participant \#11)

- "Spelled that wrong." [Changes afortundos to afortunados after spell checker underlines it.] (Participant \#12)

The $95.2 \%$ accuracy rate for spell checker usage paints a much more positive picture of this tool than Rimrott and Heift (2008). The discrepancy may well be related to the differential language learning experience among 
the participants in the two studies. Specifically, the sixth-semester learners in our study were likely producing language that more closely resembled that of native speakers, for whom spell checkers and grammar checkers are designed, than did the language produced by Rimrott and Heift's first- and second-semester German learners.

Indeed, the vast majority of the uses of the spell checker in the current study were to correct errors of the single-edit variety: objecto $\rightarrow$ objeto, porblemas $\rightarrow$ problemas, bronzeada $\rightarrow$ bronceada, tobaco $\rightarrow$ tabaco. These are the same types of errors that Rimrott and Heift (2008) found the spell checker to be most successful at correcting in L2 German. On the rare occasion that the spell checker did not lead learners to a targetlike solution, it was often because the error was of the multiple-edit type. For example, when trying to express the adjective "frequent," writing the word frequenta led one learner to select the incorrect suggestion of frecuenta instead of frecuente.

Microsoft Word's grammar checker, little researched in the L2 writing literature, also proved to be an effective tool for learners. All but two of the participants in the study referenced it at some point to make changes related to, for example, adjective-noun agreement (muchas golpes $\rightarrow$ muchos golpes), subject-verb agreement (ellos parece $\rightarrow$ ellos parecen), and contractions (a el niño $\rightarrow$ al niño). The grammar checker also frequently detected the incorrect form of a word that means different things with and without an accent mark (e.g., mas/más, tenia/tenía). There were, in fact, a total of only three instances where the use of the grammar checker led to a non-target-like form (e.g., flagging the correct el policía and suggesting la policía instead, to describe a male police officer).

Though the grammar checker seldom made incorrect suggestions in the current study, it did fail to identify a substantial number of grammatical errors. Such mistakes varied in nature, including, for example, those related to: the direct object marker a (puede encontrar a la luz), noun-adjective agreement (la palabra está escrito), use of object pronouns (lo me ayuda), verb tense/mood/aspect (después de termino la tarea), and subject-verb agreement (el niño rompi la ventana). And, while the grammar checker at times identified incorrect uses of existing words in Spanish (such as those that can appear with or without an accent mark), it frequently failed to do 
so. As such, what were essentially misspellings like pulsara (instead of pulsera) and rozado (in place of rosado) went undetected. In this sense, the modern-day grammar checker remains insufficient in its ability to identify common errors, though relatively dependable in the suggestions it does make.

Given these limitations of the grammar checker and the stilldeveloping control of the L2 among participants, morphological and syntactic errors such as those just mentioned were common in the current study - almost double that of vocabulary and spelling errors combined. This prevalence of grammatical mistakes parallels the findings of BardoviHarlig and Bofman (1989), Ferris (2002), and Elola and Mikulski (2016), and makes sense given the frequent and successful consultation of online resources for lexical questions and the high level of effectiveness of the spell checker. This finding conflicts, however, with those of Chastain (1990), who also studied upper-level L2 Spanish majors and minors but found a predominance of vocabulary errors. This discrepancy may be related to how Chastain operationalized vocabulary errors, including therein instances of extra or missing words, which fell within the realm of grammar errors in the current study. Furthermore, Chastain makes no mention of the use of dictionaries by his participants, though learners in our study referred to them regularly.

Considering the frequency of grammatical errors in our study, which was more than double that observed by Elola and Mikulski (2016) for their L2 Spanish learners, this is an area where pedagogical intervention would be helpful for some intermediate L2 writers. Such intervention might start by demonstrating the limitations of contemporary grammar checkers, pointing out the types of errors they do and do not currently detect. This could be followed by a proofreading workshop, using authentic student compositions to practice identifying and correcting especially the kinds of errors that are common at this proficiency level and that grammar checkers miss. These are often mistakes with structures that learners have studied frequently and know how to use correctly when they take the time to focus on them, such as noun-adjective and subject-verb agreement. This sort of activity can help L2 learners not to rely too heavily on the word processing tools available to them, but rather to use those tools to complement their 
own revising skills. It might even be beneficial to counsel students to turn off the spell checker and grammar checker until after they've finished composing, in order to avoid the distraction that Buck (2008) describes and which many participants in the current study experienced as colored lines suddenly appeared underneath the text they had just written.

Our findings also indicate that intermediate L2 Spanish writers need guidance in the selection and use of online resources, which were not all equally effective in facilitating the production of target-like language. This might begin with a demonstration of some of the benefits and pitfalls of various popular online dictionaries and translators, followed by a short workshop in which students use these resources to help express problematic words or phrases. In this way, we can foster discriminating and skillful users of online tools.

Pedagogical intervention can also be more logistical in nature, such as helping learners to set proofing and keyboard languages and to understand the difference between the two, something which proved challenging for several learners in this study. Once the desired keyboard has been chosen, students need to learn how to make accent marks, tildes, and other special characters and to practice doing so. The generation of such characters was, in fact, a common source of comment during the think-aloud protocol of the last composition, which revealed lingering concerns such as:

- "I need to turn the language, bar on...I don't know how to do the accents....Maybe this [the US-International Keyboard button] is it. There... There we go." (Participant \#4)

- "I still have not figured out how to use, uh, the keyboard to create accents and stuff on this computer. It's very confusing, unlike Macs and stuff." (Participant \#9)

- "Oop, there it goes again [capital Ñ]. What do I keep pressing?" (Participant \#11)

Such frustrations may help to explain why, despite the fact that the word processor's proofing tools are not sufficient to catch all errors involving special characters and diacritics, in over $25 \%$ of compositions no effort was made to generate a single one. Researchers, for their part, will find many and varied themes yet to be investigated with respect to the 
writing of L2 learners. How, for example, does the use of proofing tools compare in the L1 and the L2? How does the resource usage observed in this study compare to how a similar group of learners would write a highstakes composition? Would the approach observed here differ significantly if learners were writing on their own computers outside of the computer lab? How does the writing of the current population compare to that of higher and lower proficiency students? What percentage of the vocabulary looked up online while composing do learners retain in the short and long term? Which of these words would we expect them to already know at a given level? Answers to these and related questions will help us to further understand the challenging process behind the compositions that learners write, and in turn to intervene ever more effectively.

\section{Acknowledgements}

This project was supported by a Partnership-in-Learning grant from the University of Saint Thomas and the diligent and skillful efforts of research assistant Ms. Mary-Catherine Carranza. My thanks go to them, as well as to the editorial board of ELIA for its assistance in the preparation of this manuscript.

\section{Notes}

${ }^{1}$ Not counted as consultations of the spell checker or grammar checker were instances where participants corrected a flagged error on their own, without consulting the provided suggestions.

${ }^{2}$ The generation of special characters and diacritics was not analyzed in this same way. Rather, though it took some participants longer than others to accomplish the task, all participants eventually succeeded in producing the characters they wanted. That does not mean that, for example, all needed accent marks were present or appropriately placed. However, such cases were tracked as spelling errors as opposed to unsuccessful attempts to make an accent mark. 
${ }^{3}$ These were not counted as uses of the spell checker/grammar checker.

${ }^{4}$ Microsoft Word included pristiño as its first suggestion, despite the fact that the word does not appear in common dictionaries, such as that of the Real Academia Española.

${ }^{5}$ Elola and Mikulski (2016) also computed time somewhat differently than in the current study. For example, they included any time between the end of the composition and closing the word processor, whereas such time was not counted in this study.

\section{References}

Bardovi-Harlig, K., \& Bofman, T. (1989).Attainment of syntactic and morphological accuracy by advanced language learners. Studies in Second Language Acquisition, 11, 17-34. https://doi.org/10.1017/S0272263100007816

Bleichmar, G., \& Cañón, P. (2012). Taller de escritores: Grammar and composition for advanced Spanish. Boston, MA: Vista Higher Learning.

Bosher, S. (1998). The composing processes of three Southeast Asian writers at the post-secondary level: An exploratory study. Journal of Second Language Writing, 7, 205-241. https://doi.org/10.1016/S1060-3743(98)90013-3

Buck, A. M. (2008). The invisible interface: MS word in the writing center. Computers and Composition, 25, 396-415. https://doi.org/10.1016/j. compcom.2008.05.003

Burston, J. (2001). Exploiting the potential of a computer-based grammar checker in conjunction with self-monitoring strategies with advanced level students of French. CALICO Journal, 18, 499-515. Retrieved from http://www.jstor. org/stable/24148035

Chastain, K. (1990). Characteristics of graded and ungraded compositions. The Modern Language Journal, 74, 10-14. https://doi. org/10.1111/j.1540-4781.1990.tb02547.x

Chenoweth, N. A., \& Hayes, J. R. (2001). Fluency in writing: Generating text in L1 and L2. Written Communication, 18, 80-98. https://doi.org/10.1177\% 2F0741088301018001004

ELIA 17, 2017, pp. 157-182ＤOI:http://dx.doi.org/10.12795/elia.2017.i17.07 
Christianson, K. (1997). Dictionary use by EFL writers: What really happens? Journal of Second Language Writing, 6, 23-43. https://doi.org/10.1016/ S1060-3743(97)90004-7

Elola, I., \& Mikulski, A. M. (2016). Similar and/or different writing processes?: A study of Spanish foreign language and heritage language learners. Hispania, 99, 87-102. https://doi.org/10.1353/hpn.2016.0000

Elola, I., Rodríguez-García, V., \& Winfrey, K. (2008). Dictionary use and vocabulary choices in L2 writing. Estudios de Lingüistica Inglesa Aplicada, 8, 63-89.

Ferris, D. R. (2002). Treatment of error in second language student writing. Ann Arbor, MI: University of Michigan.

Frankenberg-Garcia, A. (2011). Beyond L1-L2 equivalents: Where do users of English as a foreign language turn for help? International Journal of Lexicography, 24, 97. https://doi.org/10.1093/ijl/ecq038

Goldberg, D., Looney, D., \& Lusin, N. (2015). Enrollments in languages other than English in United States institutions of higher education, fall 2013. Modern Language Association. Retrieved from: http:/www.mla.org/ pdf/2013_enrollment_survey.pdf

Heift, T., \& Schulze, M. (2007). Errors and intelligence in computer-assisted language learning: Parsers and pedagogues. New York, NY: Routledge.

Jin, L., \& Deifell, E. (2013). Foreign language learners' use and perception of online dictionaries: A survey study. MERLOT Journal of Online Learning and Teaching, 9, 515-532. Retrieved from: http://jolt.merlot.org/vol9no4/ jin_1213.pdf

Krapels, A. R. (1990). An overview of second language writing process research. In B. Kroll (Ed.), Second language writing: Research insights for the classroom (pp. 37-56). Cambridge, UK: Cambridge University Press. https://doi.org/10.1017/CBO9781139524551.007

Kroll, B. (1990). What does time buy? ESL student performance on home versus class compositions. In B. Kroll (Ed.), Second language writing: Research insights for the classroom (pp. 140-154). Cambridge, UK: Cambridge University Press. https://doi.org/10.1017/CBO9781139524551.014

ELIA 17, 2017, pp. 157-182～DOI:http://dx.doi.org/10.12795/elia.2017.i17.07 
Kuiken, F., \& Vedder, I. (2007). Task complexity and measures of linguistic performance in L2 writing. International Review of Applied Linguistics in Language Teaching, 45, 261-284. https://doi.org/10.1515/iral.2007.012

Loucky, J. P. (2010). Comparing electronic dictionary functions and use. CALICO Journal, 28, 156-174. https://doi.org/10.11139/cj.28.1.156-174

Manchón, R. M., Roca de Larios, J., \& Murphy, L. (2000). An approximation to the study of backtracking in L2 writing. Learning and Instruction, 10, 1335. https://doi.org/10.1016/S0959-4752(99)00016-X

Mikulski, A., \& Elola, I. (2011). Spanish heritage language learners' allocation of time to writing processes in English and Spanish. Hispania, 94, 715-733. Retrieved from https://muse.jhu.edu/article/461903

O'Neill, E. M. (2012). The effect of online translators on L2 writing in French (Doctoral dissertation). Retrieved from ProQuest Dissertations Publishing. (1447020851)

Pennington, M. C. (1999). The missing link in computer-assisted writing. In K. Cameron (Ed.), CALL: Media, design \& applications (pp. 271-292). Lisse, Netherlands: Swets \& Zeitlinger.

Pennington, M. C. (2004). Electronic media in second language writing: An overview of tools and research. In S. Fotos, \& C. M. Browne (Eds.), New perspectives on CALL for second language classrooms (pp. 69-92). Mahwah, NJ: Lawrence Erlbaum Associates.

Pennington, M. C., \& Brock, M. N. (1992). Process and product approaches to computer-assisted composition. In M. C. Pennington, \& V. Stevens (Eds.), Computers in applied linguistics: An international perspective (pp. 79109). Clevedon, UK: Multilingual Matters.

Rimrott, A., \& Heift, T. (2008). Evaluating automatic detection of misspellings in German. Language, Learning \& Technology, 12(3), 73-92. Retrieved from http://lt.msu.edu/vol12num3/rimrottheift.pdf

Roca de Larios, J., Marín, J., \& Murphy, L. (2001). A temporal analysis of formulation processes in L1 and L2 writing. Language Learning, 51, 497538. https://doi.org/10.1111/0023-8333.00163

ELIA 17, 2017, pp. 157-182ＤOI:http://dx.doi.org/10.12795/elia.2017.i17.07 
Roca de Larios, J., Murphy, L., \& Marín, J. (2002). A critical examination of L2 writing process research. In S. Ransdell, \& M. Barbier (Eds.), New directions for research in L2 writing (pp. 11-47). Dordrecht, Netherlands: Kluwer Academic Publishers. https://doi.org/10.1007/978-94-010-03636 2

Schilperoord, J. (1996). The distribution of pause time in written text production. In G. Rijlaarsdam, H. van den Bergh \& M. Couzijn (Eds.), Theories, models and methodology in writing research (pp. 21-35). Amsterdam, Netherlands: Amsterdam University Press.

Zamel, V. (1983). The composing processes of advanced ESL students: Six case studies. TESOL Quarterly, 17, 165-187. https://doi.org/10.2307/3586647 


\section{APPENDIX}

\section{Composition Topics}

Composition 1: Describan las características objetivas y sus impresiones subjetivas del objeto seleccionado.

Composition 2: Narren la historia que acaban de ver en la película muda.

Composition 3: En La generación de los mil euros, Carolina dice que no viven mal, pero que su vida "no es lo que esperábamos". En su opinión, ¿deben los jóvenes aspirar a más, o es necesario ser realista y conformarse? (Bleichmar \& Cañón, 2012)

Composition 4: Algunas personas opinan que se debe ilegalizar la compra, la venta y el uso del tabaco en los EE.UU. ¿Les parece una buena idea o no? Escriban algunos argumentos a favor de o en contra de esta idea.

Composition 5: Elijan una de las siguientes situaciones y escriban una descripción de lo que harían:

- Si supiera que solo me quedaba un año de vida ...

- Si fuera el/la presidente de la universidad ...

- Si pudiera conocer a cualquier persona del presente o del pasado ...

First version received: June 2017

Final version accepted: October 2017

ELIA 17, 2017, pp. 157-182～DOI:http://dx.doi.org/10.12795/elia.2017.i17.07 